\title{
Investigating the role of unified theory of acceptance and use of technology (UTAUT) in inter- net banking adoption context
}

\author{
Samar Rahi ${ }^{*}$, Mazuri Abd. Ghani ${ }^{\mathrm{b}}$, Feras MI Alnaser ${ }^{a}$ and Abdul Hafaz Ngah
}

${ }^{a}$ PhD scholar, Universiti Sultan Zainal Abidin, Terengganu, Malaysia

${ }^{b}$ Senior Lecturer, Universiti Sultan Zainal Abidin, Terengganu, Malaysia

${ }^{c}$ Senior Lecturer, School of Maritime Business and Management, Universiti Malaysia Terengganu, Malaysia

\section{H R O N I C L E}

Article history:

Received: November 26, 2017

Received in revised format: November 26, 2017

Accepted: January 18, 2018

Available online:

January 18, 2018

Keywords:

Internet Banking

Performance Expectancy

Effort Expectancy

Social Influence

Facilitating Condition

UTAUT

Structural Equation Modeling

(SEM)

\section{A B S T R A C T}

\begin{abstract}
Several studies have made known that internet banking (IB) implementation is not only advantageous for banks, but also by perception and experience of IB users. Therefore, little is known about factors propelling user's intention to adopt internet banking in Pakistan. Thus, the purpose of this research is to investigate the role of unified theory of acceptance and use of technology (UTAUT) in internet banking adoption context. A quantitative approach based survey was conducted to collect the data from 398 internet banking users. For statistical analysis structural equation model (SEM) approach was used. The result of this study indicates that, UTAUT model provided a good theoretical foundation in technology adoption investigation. Findings confirmed that all four predictors (performance expectancy, effort expectancy, social influence and facilitating condition) were significant and had significant amount of variance in predicting user's intention to adopt internet banking. Additionally, the IPMA test revealed that performance expectancy was the most important factor among all other variables to predict user's intention towards adoption of internet banking. Lastly, managerial implications, limitations and future recommendations are discussed.
\end{abstract}

(C) 2018 by the authors; licensee Growing Science, Canada

\section{Introduction}

E-Commerce is an application of information technology to facilitate business exchanges among different parties. The first online banking service which introduced the internet banking was established in 1994 by Stanford Federal Credit Union (SFCU). According to Yoon (2010) internet banking involves provision of facilities such as accessing accounts, funds transfer, and buying financial products or services online. Internet banking is a banking channel that allows consumers to do a wide range of financial and nonfinancial services through a bank's website (Hoehle et al., 2012).

Internet banking is forecasted to grow sharply within the next few years, affecting the competitive advantage enjoyed by traditional branch bank (Samar et al., 2017). These days in competitive business

* Corresponding author

E-mail address: sr_adroit@yahoo.com (S. Rahi) 
environment, companies must understand that customers hold the key to success (Alnaser et al., 2018). For banks, technology has emerged as a strategic resource for achieving higher efficiency, control of operations, productivity and profitability. For customers, it is the understanding of their anywhere, anytime, anyway banking dream. At the basic level, Internet banking can mean setting up of a web page by a bank to give information about its product and services. At an advance level, it involves provision of facilities such as accessing accounts, funds transfer, and buying financial products or services online. This is called "transactional" online banking (Sathye, 1999). The Internet is believed to change the way firms interact with their customers and thus the way they initiate, develop and terminate relationships with them (Rahi \& Ghani, 2016).

Customer choose internet banking because it is convenient and have speedy action (Gupta et al., 2008). Now trend has changed for customer internet banking is convenient while for banking it is a source of cost reduction and better customer service. Liao and Cheung (2002) explained, one of the major forces behind the changes happening to business is technology, which is creating new products, services market opportunities and developing more information and system oriented business and management processes. Information technology is a powerful tool or enabler in the arena of customer service. Weick and Quinn (1999) argued that, with new technologies executives can manage the strategic elements to achieve competitive advantage with minimum transaction costs. Internet banking would help banks present a potentially low cost banking transaction system.

Owing to the adoption of internet banking services will not only beneficial for banks but it will also give the opportunity to banks to satisfy their customers from a distance (Xue et al., 2011). In spite of this, banks are still finding difficulties to fully maximize their operations and this attributes to customer's unwillingness to adopt internet banking irrespective of the benefits (Martins et al., 2014). Thus, the present study investigates the role of UTAUT in internet banking adoption context. Practically this study will help managers understand customer behaviours and their intentions on how they can perform a transaction via online system that is convenient and cost effective, meanwhile policy makers will get deep insight of their clients that why majority of the banking customers are reluctant to use internet banking.

\section{Literature Review}

\subsection{Theoretical Background}

Several studies exist that explore adoption issues of technology therefore, very little research has been done on internet banking adoption issues (Rahi et al., 2017). The most known technology acceptance model (TAM) was designed to investigate the user acceptance of information technology. Basically, TAM is an adaptation of theory of reasoned action (TRA) that proposed system use evaluate by intention of use which is further influenced by attitude and perceived usefulness. Attitude and Perceived usefulness are affected by Perceived ease of usefulness. Perceived usefulness, where user salient belief will be helpful for improving the performance. According to Taylor and Todd (1995) perceived ease of usefulness is a situation where user acts stress free while using of technology. Further research was conducted by other researchers and developed a new model of technology adoption namely; Unified Theory of Acceptance and use of Technology (UTAUT). Since 2003, researchers have applied and tested UTATU model to understand the user's behaviour towards adoption of technology. It was incorporated to understand online bulletin boards study by Marchewka et al. (2007), instant messengers study by Lin and Anol (2008), and Web-based learning by Chiu and Wang (2008). In internet banking adoption context was studied by Tan et al. (2010). UTAUT model was also studied in cultural context, Im et al. (2011) underpinned the UTAUT model in comparing mp3 player and Internet banking technologies in Korea and the US, while, Yuen et al. (2010) tested the UTAUT model in two groups, that were culturally different i.e. the developed (US and Australia) and developing (Malaysia) countries. 


\subsection{UTAUT Framework}

Unified theory of acceptance and use of technology is the most unique theory which includes dimensions of TRA, TAM, Motivational Model (Davis et al., 1992). TPB is a hybrid model that combines constructs of TAM and TPB (C-TAM-TPB) (Taylor \& Todd, 1995), meanwhile, Model of PC Utilization (MPCU) proposed by Thompson et al. (1991), Innovation Diffusion Theory (IDT) by Moore and Benbasat (1996), and lastly Social Cognitive Theory (SCT) by Compeau and Higgins (1995). The UTAUT model postulates that performance expectancy, effort expectancy, social influence and facilitating conditions are the determinants of behavioural intention of users towards adoption of technology.

\subsubsection{Performance Expectancy}

Performance expectancy (PE), where user perception of performance excel by use of Internet banking on tasks, i.e., individual believes that using Internet banking will help to attain benefits in performing banking operations (Venkatesh et al., 2003). Zhou et al. (2010) elaborated that performance expectancy reflects user's perception towards improvement by using of internet banking like convenience of payment, fast response and service effectiveness. Performance expectancy in other models was described as perceived usefulness, relative advantage, outcome expectancy and extrinsic motivation. In relation to internet banking Alalwan et al. (2014) postulated that performance expectancy is considered as term of utility that encounter during use of internet banking. Performance expectancy has been widely used in order to understand the behavioral intention of users to adopt internet banking (AbuShanab et al., 2010; Martins et al., 2014). Thus, performance expectancy is hypothesized as:

\section{H1: Performance expectancy is positively influence on user's intention to adopt internet banking.}

\subsubsection{Effort Expectancy}

Effort expectancy (EE) is defined as the degree of ease relate with the use of internet banking. Effort expectancy is similar to perceived ease of use (TAM) and complexity (DOI, MPCU). Zhou et al. (2010) demonstrated that when user feels that internet banking is easy to use and does not require much effort, they would have high chances to adopt internet banking. The relationship of effort expectancy on behavioral intention has found significant (Moore \& Benbasat, 1991; Thompson et al., 1991). Effort expectancy is positively affect performance expectancy for instance, when users feel that Internet banking is easy to use, and not much efforts are required they will have a high expectation towards acquiring the expected performance (Zhou et al., 2010). Thus, the relationship of effort expectancy is proposed as:

\section{H2: Effort expectancy is positively influence on user's intention to adopt internet banking.}

\subsubsection{Social Influence}

Social influence (SI) is defined as the effect of environmental factors, for instance the opinions of user's friends, relatives (Venkatesh et al., 2003). Like other constructs of UTAUT social influence was derived from subjective norm, social factors and image. The comparison of eight models revealed that the relationship of social influence will be insignificant in voluntary context and becomes significant in mandatory context. According to Martins et al. (2014), social influence will affect user's intention to adopt internet banking services. Similar to this Chaouali et al. (2016) postulated that an individual who believes that important others believe his usage of new product or services will be more inclined to use these products or technology services. Thus, in views of above arguments social influence is hypothesized as: 
H3: Social influence is positively influence on user's intention to adopt internet banking.

\subsubsection{Facilitating Condition}

Facilitating conditions (FC) is defined as the effect of organizational and technical infrastructure to support the use of Internet banking, such as user's knowledge, ability, and resources (Venkatesh et al., 2003). Facilitation condition was similar as perceived behavioural control and compatibility. Authors like Venkatesh et al. (2012) stated that facilitating condition refers to consumers perception of the resources and support available to perform a behaviour. In order to perform internet banking users requires to have certain skills such as configuring and operating computers and connecting to the internet (Martins et al., 2014). Thus, facilitating condition is hypothesised as:

H4: Facilitating condition is positively influence on user's intention to adopt internet banking.

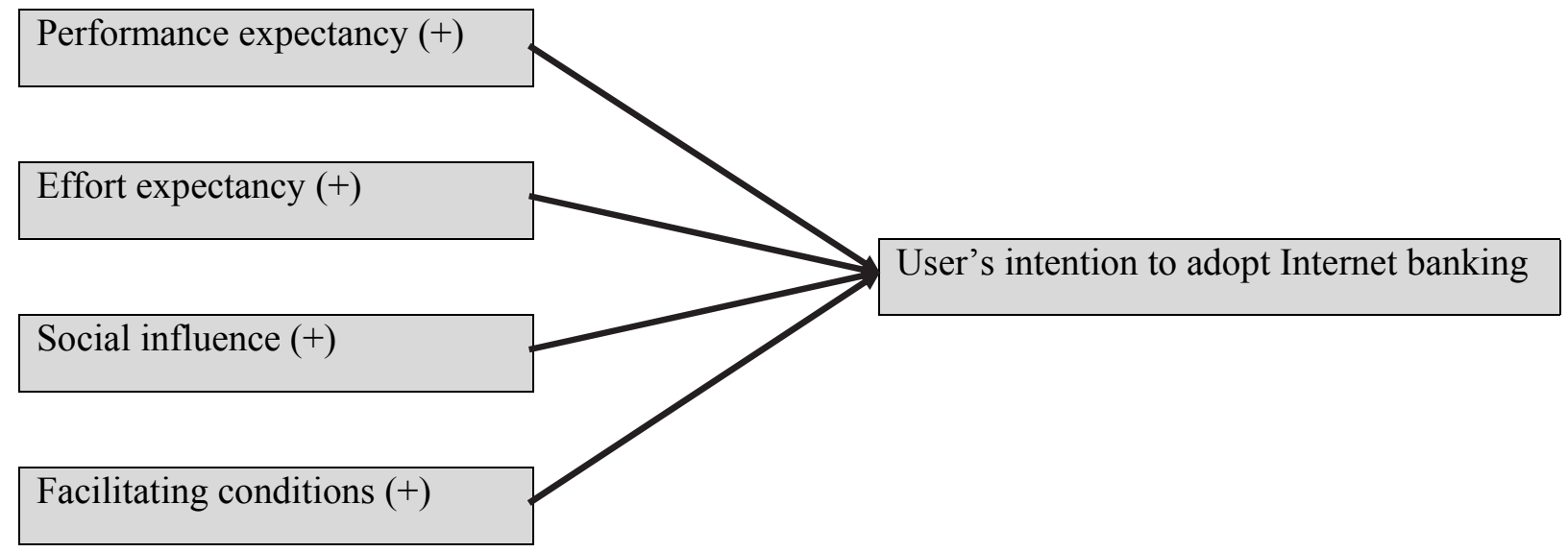

Fig. 1. Theoretical framework

\section{Research Methods}

\subsection{Data collection and Sampling}

Quantitative approach was used to verify the influence of unified theory of acceptance and use of technology on user's intention to adopt internet banking in Pakistan. This study is followed positivists paradigm. Positivists believe in employing quantitative approaches for data analysis and support objectivity to define their ontological statements (Mazuri et al., 2017). Thus, questionnaire was developed to measure the respondent's observation and perception towards internet banking technology. The survey was conducted in two large cities namely Lahore and Islamabad in order to have an appropriate sample representativeness of the population.

For sampling, convenience sampling method was used in this study. Convenience sampling is defined as a process of data collection from population that is close at hand and easily accessible to researcher (Rahi, 2017). Hair (2003) illustrated that convenience sampling allows researcher to complete interviews or get responses in a cost effective way. Seven hundred and fifty internet banking users were approached to get their observations towards internet banking adoption. The participation was voluntary and the survey was conducted over the period of one month from 09 September 2017 to 10 October 2017. Bank staff were requested to complete the survey within a period of four week. Therefore, three hundred and ninety eight (398) valid questionnaires with a response rate of 53\% were received for data analysis. 


\subsection{Measurement}

A questionnaire was developed for the survey using construct and items from literature. The questionnaire was created and administrated in English language. The survey questionnaire is divided into two parts. The first part of the questionnaire is inquired demographic profile of the respondents. While, the second part of the questionnaire holds measurement items of performance expectancy, effort expectancy, social influence, facilitating condition and users intention to adopt internet banking and are adapted from Venkatesh et al. (2012) and Rahi et al. (2017). Each item was measured on a seven-point Likert scale, ranging from 1 (strongly disagree) to 7 (strongly agree).

\subsection{Respondent's Profile}

Sample demographics are depicted in Table 1. Majority of the respondents were females $(58.5 \%)$ while males were $(41.5 \%)$. The age of the respondents $8.5 \%$ is for less than 20 years, $38.4 \%$ that counts at age between 21 to 30 years, $24.4 \%$ for 31 to 40 years, $12.1 \%$ for those respondents who have age between 41 to 59 years, $11.1 \%$ was customer having age 51 to 60 and above 60 there were only $5.5 \%$ respondents.

The study also assessed the education level of the respondents. Findings revealed that most of the participants had graduate level qualification $(n=198,49.7 \%)$ followed by those who had post graduate qualification $(\mathrm{n}=121,30.4 \%)$. The number of respondents who had attended high school were only 41 , and 27 respondents who had attended high school. While the participant who had qualification below high school were at the lowest level $(n=11,2.8 \%)$. These findings revealed that the educated respondents were more inclined towards internet banking as compared with uneducated respondents (below high School, 2.8\%).

This study has revelaed the occupation of the respondents. The results showed that the highest number of respondets were employed $(n=223,56 \%)$ followed by unemployed participants $(n=71,17.8 \%)$. There were only 55 respondents with self-employed title. The respondets with pensioner had the second lowest number $(n=33,8.3 \%)$ while students had the lowest number $(n=16,4 \%)$.

\section{Table 1}

Demographic Profile of the Respondents

\begin{tabular}{llll}
\hline Demographic & Category & Frequency (n=398) & Percentage (\%) \\
\hline Gender & Male & 165 & 41.5 \\
& Female & 233 & 58.5 \\
\hline Age & $<20$ & 34 & 8.5 \\
& $21-30$ & 153 & 38.4 \\
& $31-40$ & 97 & 24.4 \\
& $41-50$ & 48 & 12.1 \\
& $51-60$ & 44 & 11.1 \\
\hline Education (Level) & $>60$ & 22 & 5.5 \\
& Below High School & 11 & 2.8 \\
& Attended High School & 27 & 6.8 \\
& Attended College & 41 & 10.3 \\
& Graduate & 198 & 49.7 \\
\hline Occupation & Post Graduate & 121 & 30.4 \\
\hline & Student & 16 & 4 \\
& Employed & 223 & 56 \\
& Self-employed & 55 & 13.8 \\
& Unemployed & 71 & 17.8 \\
& Pensioner & 33 & 8.3 \\
\hline
\end{tabular}

Note: (--) denotes $0 \%$ of the total respondents 


\section{Data Analysis and Results}

Structural equation modeling (SEM) is a technique for estimating the causal relationship among variables. There are two types of SEM techniques namely covariance-based technique and variance based techniques. The variance based technique using Partial Least Square (PLS) is appropriate for this study. Smart PLS3.0 software is used to estimate the research model (Ringle et al., 2015). Following twostage analytical procedure, measurement model is analysed first to assess the reliability and the validity and then structural model is tested.

\subsection{Measurement Model}

The measurement model was evaluated for construct reliability, indicator reliability, convergent validity and discriminant validity. Cronbach's $(\alpha)$ is recommended to ensure reliability therefore, Composite Reliability (CR) is also preferred (Henseler et al., 2009).

\subsection{Convergent Validity}

Convergent validity is ascertained by examining indicator loadings. Fig. 2 depicted results where, factor loading values supported by Chin (1998) as recommended threshold level of 0.6. All the values were above than 0.6 which indicate the convergent validity.

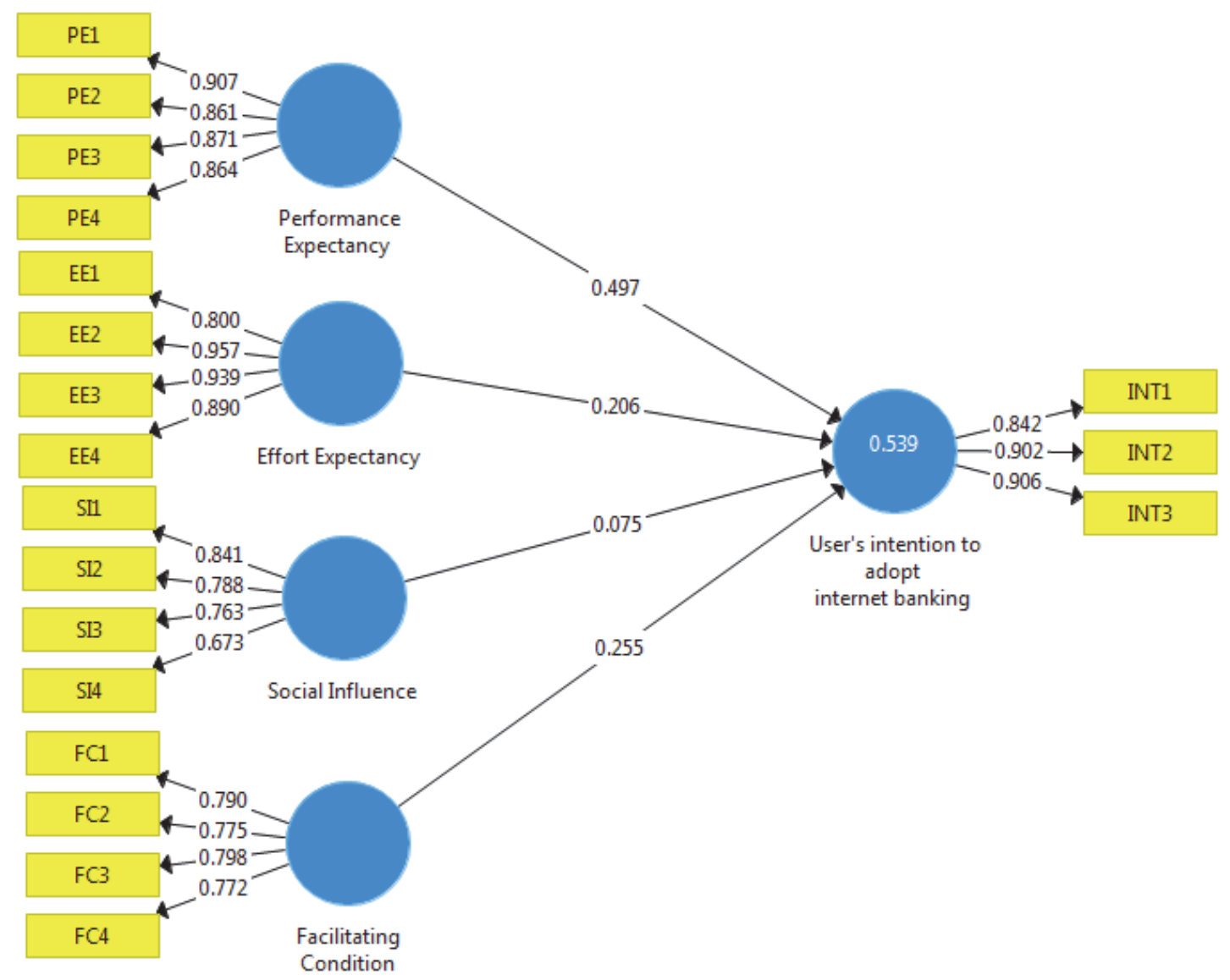

Fig. 2. Measurement model 
Convergent validity of measurement model is also assessed through average variance extracted and compost reliability. The average variance extracted that reflects the overall amount of variance in the indicators accounted for latent construct. Further to this measurement model needs to be assess composite reliability. Thus, the convergent validity was confirmed through estimation of average variance extracted (AVE) by recommended values of Fornell and Larcker (1981) as it must be greater than 0.5. Composite reliability (CR) degree where the construct indicator represent the latent construct, values exceeded 0.7 recommended by Hair et al. (2011). Table 2 depicted the results of measurement model.

Table 2

Results of Measurement Model

\begin{tabular}{|c|c|c|c|c|}
\hline Constructs & Loading & $(\alpha)$ & $\mathbf{C R}$ & AVE \\
\hline Performance Expectancy & PE & 0.899 & 0.930 & 0.767 \\
\hline Internet banking is useful to carry out my tasks. & 0.907 & & & \\
\hline I think that using Internet banking would enable me to conduct tasks more quickly. & 0.861 & & & \\
\hline I think that using Internet banking would increase my productivity. & 0.871 & & & \\
\hline I think that using Internet banking would improve my performance. & 0.864 & & & \\
\hline Effort Expectancy & $\mathbf{E E}$ & 0.919 & 0.944 & 0.808 \\
\hline My interaction with Internet banking would be clear and understandable. & 0.800 & & & \\
\hline It would be easy for me to become skillful by using Internet banking. & 0.957 & & & \\
\hline I would find Internet banking easy to use. & 0.939 & & & \\
\hline I think that learning to operate Internet banking would be easy for me. & 0.890 & & & \\
\hline Social Influence & SI & 0.774 & 0.852 & 0.591 \\
\hline People who influence my behavior think that I should use Internet banking. & 0.841 & & & \\
\hline People who are important to me think that I should use Internet banking. & 0.788 & & & \\
\hline People in my environment who use Internet banking services have a high profile. & 0.763 & & & \\
\hline Having Internet banking services is a status of symbol in my environment. & 0.673 & & & \\
\hline Facilitating Condition & FC & 0.791 & 0.864 & 0.615 \\
\hline I have the resources necessary to use the internet banking. & 0.790 & & & \\
\hline I have the knowledge necessary to use the internet banking. & 0.775 & & & \\
\hline Internet banking is compatible with other technologies I use. & 0.798 & & & \\
\hline A specific person is available for assistance of internet banking difficulties. & 0.772 & & & \\
\hline User's intention to adopt internet banking & INT & 0.859 & 0.914 & 0.781 \\
\hline I intend to continue using Internet banking in the future. & 0.842 & & & \\
\hline I will always try to use Internet banking in my daily life. & 0.902 & & & \\
\hline I plan to continue using Internet banking frequently. & 0.906 & & & \\
\hline
\end{tabular}

\subsection{Discriminant Validity}

Discriminant validity of the constructs was evaluated by using Fornell and Larcker (1981) . Discriminate validity is measure by examining the correlation between the measures of the potential overlapping constructs (Fornell \& Larcker, 1981). According to , (D. Compeau et al., 1999) the average variance shared between each construct and its measure should be greater than the variance shared between the constructs and other constructs. As seen in Table 3 all, all the diagonal values (square root of AVE) are greater than off-diagonal values (correlations between the construct).

Table 3

Discriminate validity of Measurement Model

\begin{tabular}{llllll}
\hline Constructs & $\begin{array}{l}\text { Effort Ex- } \\
\text { pectancy }\end{array}$ & $\begin{array}{l}\text { Facilitating } \\
\text { Condition }\end{array}$ & $\begin{array}{l}\text { Performance Ex- } \\
\text { pectancy }\end{array}$ & $\begin{array}{l}\text { Social In- } \\
\text { fluence }\end{array}$ & $\begin{array}{l}\text { User's in- } \\
\text { tention }\end{array}$ \\
\hline Effort Expectancy & $\mathbf{0 . 8 9 9}$ & & & \\
\hline Facilitating Condition & 0.14 & $\mathbf{0 . 7 8 4}$ & & \\
\hline $\begin{array}{l}\text { Performance Expectancy } \\
\text { Social Influence }\end{array}$ & 0.368 & 0.295 & $\mathbf{0 . 8 7 6}$ & 0.09 & $\mathbf{0 . 7 6 9}$ \\
$\begin{array}{l}\text { User's intention to adopt_in- } \\
\text { ternet banking }\end{array}$ & 0.119 & 0.102 & 0.655 & 0.17 & $\mathbf{0 . 8 8 4}$ \\
\hline
\end{tabular}

Note: Bold values indicate the square root of AVE of each construct 
Discriminate validity was measured with cross-loading criteria. Cross loading can be done by comparing an indicator's outer loadings on the associated constructs and it should be greater than all of its loading on the other constructs. Table 4 shows that all the loadings are greater than the correspondent cross-loadings.

\section{Table 4}

Loading and Cross Loadings

\begin{tabular}{|c|c|c|c|c|c|}
\hline Items & $\begin{array}{l}\text { Effort Expec- } \\
\text { tancy }\end{array}$ & $\begin{array}{c}\text { Facilitating Condi- } \\
\text { tion }\end{array}$ & User's intention & $\begin{array}{c}\text { Performance Expec- } \\
\text { tancv }\end{array}$ & Social Influence \\
\hline EE1 & 0.800 & 0.142 & 0.363 & 0.344 & 0.104 \\
\hline EE2 & 0.957 & 0.142 & 0.435 & 0.342 & 0.124 \\
\hline EE3 & 0.939 & 0.11 & 0.415 & 0.337 & 0.101 \\
\hline EE4 & 0.890 & 0.109 & 0.332 & 0.296 & 0.097 \\
\hline FC1 & 0.159 & 0.790 & 0.346 & 0.241 & 0.068 \\
\hline FC2 & 0.156 & 0.775 & 0.34 & 0.259 & 0.079 \\
\hline FC3 & 0.066 & 0.798 & 0.343 & 0.234 & 0.077 \\
\hline FC4 & 0.059 & 0.772 & 0.346 & 0.192 & 0.096 \\
\hline INT1 & 0.337 & 0.367 & 0.842 & 0.569 & 0.118 \\
\hline INT2 & 0.443 & 0.383 & 0.902 & 0.566 & 0.163 \\
\hline INT3 & 0.366 & 0.411 & 0.906 & 0.601 & 0.168 \\
\hline PE1 & 0.302 & 0.255 & 0.564 & 0.907 & 0.052 \\
\hline PE2 & 0.393 & 0.284 & 0.612 & 0.861 & 0.143 \\
\hline PE3 & 0.299 & 0.285 & 0.599 & 0.871 & 0.071 \\
\hline PE4 & 0.286 & 0.199 & 0.508 & 0.864 & 0.040 \\
\hline SI1 & 0.075 & 0.08 & 0.164 & 0.059 & 0.841 \\
\hline SI2 & 0.148 & 0.117 & 0.125 & 0.076 & 0.788 \\
\hline SI3 & 0.093 & 0.071 & 0.134 & 0.073 & 0.763 \\
\hline SI4 & 0.044 & 0.034 & & 0.08 & 0.673 \\
\hline
\end{tabular}

\subsubsection{Heterotrait-Monotrait Ratio (HTMT)}

An alternative method to assess discriminant validity is suggested by Henseler et al. (2015). Discriminant validity can be assessed through multitrait and multimethod matrix, namely the Heterotrait-Monotrait Ratio (HTMT).

Table 5

Heterotrait-Monotrait Ratio (HTMT)

\begin{tabular}{|c|c|c|c|c|c|}
\hline Constructs & $\begin{array}{l}\text { Effort Expec- } \\
\text { tancy }\end{array}$ & $\begin{array}{l}\text { Facilitating Con- } \\
\text { dition }\end{array}$ & $\begin{array}{l}\text { Performance Ex- } \\
\text { pectancy }\end{array}$ & $\begin{array}{l}\text { Social Influ- } \\
\text { ence }\end{array}$ & INT \\
\hline Effort Expectancy & --- & & & & \\
\hline Facilitating Condition & $\begin{array}{c}0.164 \\
\text { CI:90 } \\
(0.082,0.261)\end{array}$ & & & & \\
\hline Performance Expectancy & $\begin{array}{c}0.402 \\
\text { CI: } 90 \\
(0.32,0.491)\end{array}$ & $\begin{array}{c}0.346 \\
\text { CI: } 90 \\
(0.272,0.426)\end{array}$ & & & \\
\hline Social Influence & $\begin{array}{c}0.138 \\
\text { CI:90 } \\
(0.067,0.23)\end{array}$ & $\begin{array}{c}0.125 \\
\text { CI:90 } \\
(0.055,0.191)\end{array}$ & $\begin{array}{c}0.109 \\
\text { CI:90 } \\
(0.051,0.169)\end{array}$ & & \\
\hline $\begin{array}{l}\text { User's intention to adopt_internet } \\
\text { banking }\end{array}$ & $\begin{array}{c}0.484 \\
\text { CI:90 } \\
(0.386,0.576)\end{array}$ & $\begin{array}{c}0.532 \\
\text { CI:90 } \\
(0.443,0.601)\end{array}$ & $\begin{array}{c}0.742 \\
\text { CI:90 } \\
(0.66,0.822)\end{array}$ & $\begin{array}{c}0.198 \\
\text { CI:90 } \\
(0.113,0.288)\end{array}$ & --- \\
\hline
\end{tabular}

\subsection{Structural Model Evaluation}

The measurement model result indicates that constructs reliability, indicator reliability, convergent validity, and discriminant validity of the construct are satisfactory. Thus, the construct can be used for 
structural model. In order to assess the structural model lateral collinearity test (VIF), $R^{2}$ values and corresponding $\mathrm{t}$-values were evaluated.

\subsection{Lateral Collinearity Assessment}

According to Kock and Lynn (2012) although vertical collinearity are met, lateral collinearity (predictor- criterion collineraity) may sometimes misled the findings. Thus, Lateral collinearity was assessed with collineraity satatistics VIF. The values of VIF 3.3 or higher, indicate a potential collinearity Diamantopoulos and Siguaw (2006). Table 6 depicted the results of lateral collinearity assessment.

\section{Table 6}

Results of Lateral Collinearity Assessment

\begin{tabular}{ll}
\hline Constructs & User's intention to adopt internet banking \\
\hline Effort Expectancy & 1.167 \\
Facilitating Condition & 1.103 \\
Performance Expectancy & 1.244 \\
Social Influence & 1.023 \\
User's intention to adopt_internet banking & --- \\
\hline
\end{tabular}

Table 6 showed the inner VIF values of the independent variables users intention to adopt internet banking that needs to be examined. The multicollinearity are less than 5 and 3.3, indicating lateral multicollinearity is not a concern in this study (Hair et al., 2014).

\subsection{Hypotheses Testing}

Hypotheses were tested by running a bootstrapping procedure with a resample of 5000, as suggested by Hair et al. (2014). Table 7 shows the PLS estimation results.

\section{Table 7}

Hypothesis Testing

\begin{tabular}{lllllll}
\hline$\#$ & Constructs & B & S.E & t-values & P-Values & Results \\
\hline H1 & PE-> INT & 0.497 & 0.048 & 10.316 & $* * *$ & Supported \\
H2 & EE-> INT & 0.206 & 0.047 & 4.384 & $* * *$ & Supported \\
H3 & SI-> INT & 0.075 & 0.032 & 2.324 & $* *$ & Supported \\
H4 & FC-> INT & 0.255 & 0.043 & 5.950 & $* * *$ & Supported \\
\hline
\end{tabular}

Note: Significance level where, ${ }^{*} \mathrm{p}<0.05,{ }^{* *} \mathrm{p}<0.01,{ }^{* * *} \mathrm{p}<0.001$

Structural model results revealed that all four hypotheses have significant relationships with their respective endogenous variables. The relationship between performance expectancy and user's intention to adopt internet banking is supported by $\mathrm{H} 1:(\beta=0.497, \mathrm{p}<0.000)$. Effort expectancy has significant influence on user's intention to adopt internet banking and supported by $\mathrm{H} 2$ : $(\beta=0.206, \mathrm{p}<0.000)$. Next to this, H3 showed that social influence is positively related wit users intention to adopt internet banking ( $\beta=0.075, p<0.001)$. Lastly, H4 is supported by $(\beta=0.255, p<0.000)$ which indicated that facilitating condition has positive influence on user's intention to adopt internet banking.

\subsection{Evaluating Effect Size}

The results of the current research show that $R^{2}$ values for user's intention to adopt internet banking was 0.539 which is acceptable as suggested by Cohen (1988). Researchers also assessed the effect size of $\left(f^{2}\right)$. As suggested by Cohen (1988) stated that $P$ value can show the effect exists however, it does not reveal the size of the effect. Thus, the effect size of $\left(f^{2}\right)$ was assessed. Additionally, predictive relevance of research model was assessed through $Q^{2}$ also known as Stone-Geisser's $Q^{2}$. Based on the blindfolding procedure, $Q^{2}$ evaluates the predictive validity of a model via PLS. $Q^{2}$ values are 
greater than 0 showed that the model has predictive relevance for a certain endogenous construct (Cohen, 1988). Table 8 shows the results of $\left(f^{2}\right)$ and $Q^{2}$.

\section{Table 8}

Evaluating Effect Size

\begin{tabular}{|c|c|c|c|c|c|}
\hline Path & $\begin{array}{l}\text { Constructs } \\
\text { Intention }\end{array}$ & $\begin{array}{c}R^{2} \\
0.453\end{array}$ & $\begin{array}{c}Q^{2} \\
0.394\end{array}$ & $f^{2}$ & Decision \\
\hline H1 & PE -> INT & & & 0.431 & Large \\
\hline $\mathrm{H} 2$ & EE -> INT & & & 0.079 & Small \\
\hline H3 & SI $->$ INT & & & 0.012 & Small \\
\hline H4 & $\mathrm{FC}->$ INT & & & 0.128 & Small \\
\hline
\end{tabular}

Note: $f^{2}: 0.02$, small; 0.15 , medium; 0.35 , large

Table 8 presents the effect size of $\left(f^{2}\right)$ and it can be seen that H2,H3 and H4 have small effect sizes, whereas H1 has a large effect size on user's intention to adopt internet banking in Pakistan. The values of $Q^{2}$ is greater than $0(0.394)$ that signifies research model has good predictive relevance.

\subsection{Importance performance matrix analysis (IPMA)}

IPMA builds on PLS estimates of the structural equation model relationship and includes an additional dimension to the analysis of that latent constructs (Hair et al., 2016). In current research model importance performance matrix analysis was performed using user's intention to adopt internet banking as the target variable. Importance performance matrix map showed that, performance expectancy has the highest importance level to influence user's intentions to adopt internet banking.

On the other side social influence has the highest performance and indicated that it is not important variable to predict user's intention to adopt internet banking. For managers, it is important to focus on performance expectancy and facilitating condition in order to increase user's intention towards adoption of internet banking. The level of importance and performance can be seen in Fig. 3.

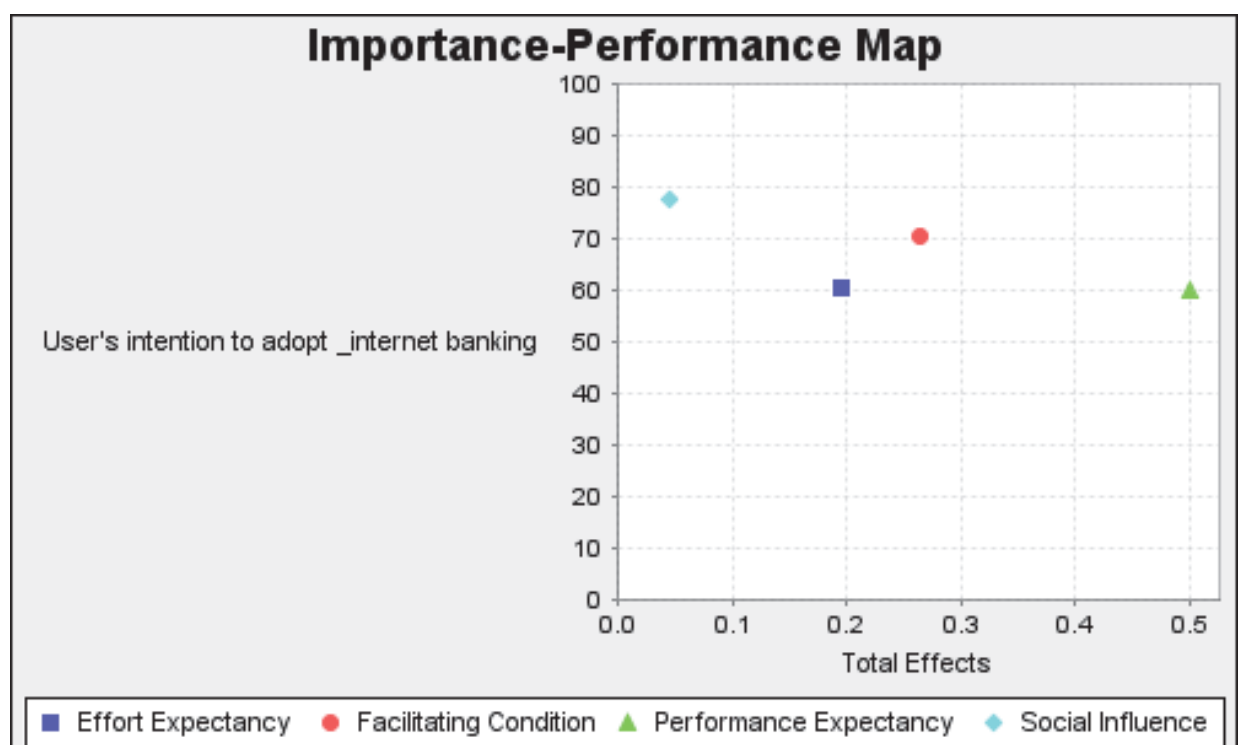

Fig. 3. Importance performance matrix analyses (IPMA) 


\section{Discussion and Conclusion}

This study extended the body of knowledge in the area of technology adoption. Previous studies have tried to find internet banking adoption issues with service quality perspective factors and had ignored the technology context in internet banking usage (Rahi, 2015, 2016). Thus, the present study has tried to examine internet banking issues with unified theory of acceptance and use of technology (UTAUT) in Pakistan. UTAUT model was developed in western culture, therefore testing of UTAUT model in South Asian country is noteworthy. The results have indicated a support of UTAUT findings with Venkatesh et al. (2003). Performance expectancy was significant with user's intention to adopt internet banking suggested that users having more performance expectancy had more inclined towards adoption of internet banking. Interestingly, the effect of sizes revealed that social influence, facilitating condition and effort expectancy had small effect sizes in predicting of user's intention to adopt internet banking.

\section{Theoretical and Managerial Implications}

In theoretical perspective, this study has tested UTAUT model in south Asian region and has proved that performance expectancy, effort expectancy, social influence and facilitating condition are the main factors in order to increase the user's intention to adopt internet banking in Pakistan. The findings of this study suggest that performance expectancy was the most influential factors among all other UTAUT factors (social influence, effort expectancy, and facilitating condition). Additionally, Importance performance matrix analysis (IPMA) also indicated that performance expectancy is the most important variable in predicting of user's intention to adopt internet banking. Thus, managerial action should be taken on the improvement of performance expectancy of the internet banking. Methodologically, this study has used structural equation modelling (SEM), to validate the measurement and structural model.

\subsection{Limitations and directions for Future Research}

Like any other research, this research has some limitations that should be considered before interpreting the findings. The first concern is generalizability of the results, since the present study has used nonprobability sampling approach. Second, this study is cross-sectional and measures the internet banking user's behaviour at one point in time that may be less generalizable as compared with longitudinal study. Future research can extend UTAUT model with other variables such as website design, assurance, reliability and e-customer service in order to get more in-depth knowledge about factors propelling user's intention to adopt internet banking.

\section{References}

AbuShanab, E., Pearson, J. M., \& Setterstrom, A. J. (2010). Internet banking and customers' acceptance in Jordan: the unified model's perspective. Communications of the Association for information systems, 26(1), 23.

Alalwan, A., Dwivedi, Y., \& Williams, M. (2014). Examining factors affecting customer intention and adoption of Internet banking in Jordan. Paper presented at the Proceedings of United Kingdom Academy of Information Systems UKAIS Conference.

Alnaser, F., Ghani, M., \& Rahi, S. (2017). The Impact of SERVQUAL Model and Subjective Norms on Customer's Satisfaction and Customer Loyalty in Islamic Banks: A Cultural Context. Int J Econ Manag Sci, 6(5), 455.

Alnaser, F. M. I., Ghani, M. A., \& Rahi, S. (2018). Service quality in Islamic banks: The role of PAKSERV model, customer satisfaction and customer loyalty Accounting 4. doi: 10.5267/j.ac.2017.8.001

Chaouali, W., Yahia, I. B., \& Souiden, N. (2016). The interplay of counter-conformity motivation, social influence, and trust in customers' intention to adopt Internet banking services: The case of an emerging country. Journal of Retailing and Consumer Services, 28, 209-218. 
Chin, W. W. (1998). Commentary: Issues and opinion on structural equation modeling: JSTOR.

Chiu, C.-M., \& Wang, E. T. (2008). Understanding Web-based learning continuance intention: The role of subjective task value. Information \& Management, 45(3), 194-201.

Cohen, J. (1988). Statistical power analysis for the behavioural sciences. Hillside. NJ: Lawrence Earlbaum Associates.

Compeau, D., Higgins, C. A., \& Huff, S. (1999). Social cognitive theory and individual reactions to computing technology: A longitudinal study. MIS quarterly, 145-158.

Compeau, D. R., \& Higgins, C. A. (1995). Computer self-efficacy: Development of a measure and initial test. MIS quarterly, 189-211.

Davis, F. D., Bagozzi, R. P., \& Warshaw, P. R. (1992). Extrinsic and intrinsic motivation to use computers in the workplace1. Journal of applied social psychology, 22(14), 1111-1132.

Diamantopoulos, A., \& Siguaw, J. A. (2006). Formative versus reflective indicators in organizational measure development: A comparison and empirical illustration. British Journal of Management, 17(4), 263-282.

F. Hair Jr, J., Sarstedt, M., Hopkins, L., \& G. Kuppelwieser, V. (2014). Partial least squares structural equation modeling (PLS-SEM) An emerging tool in business research. European Business Review, 26(2), 106-121.

Fornell, C., \& Larcker, D. F. (1981). Structural equation models with unobservable variables and measurement error: Algebra and statistics. Journal of Marketing Research, 382-388.

Gold, A. H., \& Arvind Malhotra, A. H. S. (2001). Knowledge management: An organizational capabilities perspective. Journal of Management Information Systems, 18(1), 185-214.

Gupta, M., Rao, R., \& Upadhyaya, S. (2008). Electronic Banking and Information Assurance Issues. Advances in Banking Technology and Management: Impacts of ICT and CRM.

Hair, J. F. (2003). Essentials of Business Research Methods: Wiley.

Hair, J. F., Ringle, C. M., \& Sarstedt, M. (2011). PLS-SEM: Indeed a silver bullet. Journal of Marketing Theory and Practice, 19(2), 139-152.

Hair Jr, J. F., Hult, G. T. M., Ringle, C., \& Sarstedt, M. (2016). A primer on partial least squares structural equation modeling (PLS-SEM): Sage Publications.

Henseler, J., Ringle, C. M., \& Sarstedt, M. (2015). A new criterion for assessing discriminant validity in variance-based structural equation modeling. Academy of Marketing Science. Journal, 43(1), 115.

Henseler, J., Ringle, C. M., \& Sinkovics, R. R. (2009). The use of partial least squares path modeling in international marketing. Advances in international marketing, 20(1), 277-319.

Hoehle, H., Scornavacca, E., \& Huff, S. (2012). Three decades of research on consumer adoption and utilization of electronic banking channels: A literature analysis. Decision Support Systems, 54(1), 122-132.

Im, I., Hong, S., \& Kang, M. S. (2011). An international comparison of technology adoption: Testing the UTAUT model. Information \& Management, 48(1), 1-8.

Kline, R. (2011). Principles and Practice of Structural Equation Modeling, 3rd edn Guilford Press. New York.

Kock, N., \& Lynn, G. (2012). Lateral collinearity and misleading results in variance-based SEM: An illustration and recommendations.

Liao, Z., \& Cheung, M. T. (2002). Internet-based e-banking and consumer attitudes: an empirical study. Information \& Management, 39(4), 283-295.

Lin, C.-P., \& Anol, B. (2008). Learning online social support: an investigation of network information technology based on UTAUT. CyberPsychology \& behavior, 11(3), 268-272.

Marchewka, J. T., Liu, C., \& Kostiwa, K. (2007). An application of the UTAUT model for understanding student perceptions using course management software. Communications of the IIMA, 7(2), 93.

Martins, C., Oliveira, T., \& Popovič, A. (2014). Understanding the Internet banking adoption: A unified theory of acceptance and use of technology and perceived risk application. International Journal of Information Management, 34(1), 1-13. 
Mazuri, A. G., Samar, R., Norjaya, M. Y., \& Feras, M. A. (2017). Adoption of Internet Banking: Extending the Role of Technology Acceptance Model (TAM) with E-Customer Service and Customer Satisfaction. World Applied Sciences Journal, 35(9).

Moore, G. C., \& Benbasat, I. (1991). Development of an instrument to measure the perceptions of adopting an information technology innovation. Information systems research, 2(3), 192-222.

Moore, G. C., \& Benbasat, I. (1996). Integrating diffusion of innovations and theory of reasoned action models to predict utilization of information technology by end-users Diffusion and adoption of information technology (pp. 132-146): Springer.

Rahi, S. (2015). Moderating Role of Brand Image With Relation to Internet Banking and Customer Loyalty: A Case of Branchless Banking. The Journal of Internet Banking and Commerce, 20(3).

Rahi, S. (2016). Impact of Customer Perceived Value and Customers Perception of Public Relation on Customer Loyalty with Moderating Role of Brand Image. The Journal of Internet Banking and Commerce, 21(2), ---.

Rahi, S. (2017). Research Design and Methods: A Systematic Review of Research Paradigms, Sampling Issues and Instruments Development. International Journal of Economics \& Management Sciences, $6(2)$.

Rahi, S., \& Ghani, M. A. (2016). Customer's Perception of Public Relation in E-Commerce and its Impact on E-Loyalty with Brand Image and Switching Cost. Journal of Internet Banking and Commerce, 21(3).

Rahi, S., Ghani, M. A., \& Alnaser, F. M. (2017). The Influence of E-Customer Services and Perceived Value on Brand Loyalty of Banks and Internet Banking Adoption: A Structural Equation Model (SEM). The Journal of Internet Banking and Commerce, 22(1), 1-18.

Ringle, C. M., Wende, S., \& Becker, J.-M. (2015). SmartPLS 3. Boenningstedt: SmartPLS GmbH.

Samar, S., Ghani, M., \& Alnaser, F. (2017). Predicting customer's intentions to use internet banking: the role of technology acceptance model (TAM) in e-banking. Management Science Letters, 7(11), 513-524.

Sathye, M. (1999). Adoption of Internet banking by Australian consumers: an empirical investigation. International Journal of Bank Marketing, 17(7), 324-334.

Tan, K. S., Chong, S. C., Loh, P. L., \& Lin, B. (2010). An evaluation of e-banking and m-banking adoption factors and preference in Malaysia: a case study. International Journal of Mobile Communications, 8(5), 507-527.

Taylor, S., \& Todd, P. (1995). Assessing IT usage: The role of prior experience. MIS quarterly, 561570.

Thompson, R. L., Higgins, C. A., \& Howell, J. M. (1991). Personal computing: toward a conceptual model of utilization. MIS quarterly, 125-143.

Venkatesh, V., Morris, M. G., Davis, G. B., \& Davis, F. D. (2003). User acceptance of information technology: Toward a unified view. MIS quarterly, 425-478.

Venkatesh, V., Thong, J. Y., \& Xu, X. (2012). Consumer acceptance and use of information technology: extending the unified theory of acceptance and use of technology.

Weick, K. E., \& Quinn, R. E. (1999). Organizational change and development. Annual review of psychology, 50(1), 361-386.

Xue, M., Hitt, L. M., \& Chen, P.-y. (2011). Determinants and outcomes of internet banking adoption. Management science, 57(2), 291-307.

Yoon, C. (2010). Antecedents of customer satisfaction with online banking in China: The effects of experience. Computers in Human Behavior, 26(6), 1296-1304.

Yuen, Y. Y., Yeow, P. H., Lim, N., \& Saylani, N. (2010). Internet banking adoption: Comparing developed and developing countries. Journal of Computer Information Systems, 51(1), 52-61.

Zhou, T., Lu, Y., \& Wang, B. (2010). Integrating TTF and UTAUT to explain mobile banking user adoption. Computers in Human Behavior, 26(4), 760-767. 
(C) 2018 by the authors; licensee Growing Science, Canada. This is an open access article distributed under the terms and conditions of the Creative Commons Attribution (CC-BY) license (http://creativecommons.org/licenses/by/4.0/). 